\title{
Mean Performance of Knolkhol (Brassica oleracea var. gongylodes L.) Genotypes for Various Quantitative Traits under Sub Tropical Conditions of Jammu
}

\author{
Rinchan Dolkar ${ }^{*}$, R.K. Samnotra, Sanjeev Kumar, R.K. Gupta and Sandeep Chopra \\ Division of Vegetable Science and Floriculture, Sher-e-Kashmir University of Agricultural \\ Sciences and Technology of Jammu, Chatha J\&K, India \\ *Corresponding author
}

\section{A B S T R A C T}

The present investigation entitled "Mean performance of knolkhol (Brassica oleracea var. gongylodes L.) genotypes for various quantitative traits under sub-tropical conditions of Jammu" comprising of thirty genotypes was carried out at Vegetable Research Farm,

Keywords

Variability, GCV,

PCV, Mean

performance

Article Info

Accepted:

06 May 2018

Available Online:

10 June 2018
Division of Vegetable Science and Floriculture, FOA, Chatha, SKUAST-J, Main campus, Chatha to evaluate the mean performance of knolkhol for various Quantitative traits during the year 2016-17. The field experiment was laid out in Randomized Block Design with three replications, spaced at $30 \mathrm{~cm} \times 30 \mathrm{~cm}$. The analysis of variance revealed that mean squares due to genotypes were significant for all the traits highlighting the presence of sufficient genetic variability among the genotypes. Based on the mean performance of genotypes with respect to various growth and yield attributing genotypes namely SJKK04, G-40 and Green Gold gave yield statistically at par with Early Super White Vienna which had higher yield among the genotypes studied. SJKK-04 was also found to be one of the best performers for number of leaves per plant, net knob weight per plant and gross knob weight per plant. Genotype Early Super White Vienna had maximum marketable knob diameter and took less number of days to marketable knob maturity and Pusa Virat had minimum stalk length and petiole length, respectively.

\section{Introduction}

Knolkhol (Brassica oleracea var. gongylodes L.) $2 \mathrm{n}=18$ belongs to family Brassicacea is a cool season vegetable crop. It has its primary centre of origin in Northern Europe. It is also called as kohl rabi (German word) i.e. cabbage turnip, since it resemble an above ground turnip. It has importance for both leaves and knobs consumption in India and only knobs in Europe. In India it is widely grown in Jammu and Kashmir, West Bengal and to a limited extent as a rare exotic vegetable in some parts of Maharashtra, Assam, Uttar Pradesh and Punjab (Thamburaj and Singh, 2010). Of late demand for knolkhol has gained momentum in National Capital Region of Delhi and adjoining states because of its wholesome utility as fresh vegetable and value addition products which support the food needs of the people. In Jammu and Kashmir it is a popular vegetable both among rich and poor and 
grown in almost all kitchen gardens and also as a commercial crop around cities and towns. In Jammu knolkhol is grown over an area of about 1961 ha and with a production of $54977.60 \mathrm{mt}$ (Anonymous et al., 2014) and is in great demand throughout the year for its varied size of coloured knobs and leaves. Knolkhol is a highly cross pollinated crop and shows tremendous variability in the available germplasm for most of the desirable traits. Genetic variability existing in the cultivated species either through natural processes or through crop breeding is essential for generating new gene complexes for realizing higher economic yield and resistance to biotic and abiotic stresses. There is a scanty of literature regarding the performance of various genotypes for in knolkhol. So the present study will generate the extent of variation among different genotypes for growth and yield attributing traits in knolkhol.

\section{Materials and Methods}

The present investigation was carried out under subtropical conditions of Jammu at Vegetable Experimental Farm, Division of Vegetable Science and Floriculture, Faculty of Agriculture, Sher-e-Kashmir University of Agricultural Sciences and Technology, Main Campus, Chatha, Jammu (J\&K) during (SeptOct) of the year 2016-17. The experimental field of Division of Vegetable Science and Floriculture, SKUAST, Jammu is situated at $32^{\circ} 40^{\prime} \mathrm{N}$ latitude and $74^{\circ} 58^{\prime} \mathrm{E}$ longitude and has an elevation of $332 \mathrm{~m}$ above mean sea level. The experimental material comprised of 30 diverse genotypes of knolkhol collected from diverse agro-climatic regions of $\mathrm{J} \& \mathrm{~K}$ along with two genotypes from IARI, Katrain, one from CSKHPKV, Palampur and three hybrids. The details of the genotypes along with their source are given below in Table 1 . The experimental was laid out in Randomized Block Design with three replications during (Sept-Oct) of the year 2016-17. The sowing of all genotypes was done in nursery bed and 25 days old seedlings were transplanted at the spacing of $30 \mathrm{~cm}$ between rows and $30 \mathrm{~cm}$ between plants within the rows. The package and practices to raise successful crop of knolkhol was followed. Five plants were randomly selected from each replication per genotype for recording the various growth and yield attributing traits. The mean value was used as the replicated data and was subjected to statistical analysis using INDOSTAT software package. The data of quantitative traits were statistically analyzed as per methods out lined by Panse and Sukhatme (1967) for estimating the analysis of variance (ANOVA).

\section{Results and Discussion}

\section{Analysis of variance}

The analysis of variance (ANOVA) revealed that mean squares due to genotypes were highly significant for all the traits studied, thereby exhibiting the presence of sufficient genetic variability in the genotypes (Table 2) and considerable scope for improvement of various traits such as plant height, plant frame, petiole length, number of leaves per plant, leaf length, leaf width, stalk length, gross weight /plant, marketable knob weight/plant, marketable knob diameter, harvest index, days to marketable maturity, Earlier workers namely, Santhosha et al., (2014) and Chittora and Singh (2015) have also reported variability in their respective cauliflower material for different set of characters studied.

\section{Mean performance of different genotypes}

\section{Growth traits}

Plant height ranged from $31.04 \mathrm{~cm}$ in genotype Farashi Lajwari Local to $55.78 \mathrm{~cm}$ in genotype SKKK-02 with overall general mean of $44.58 \mathrm{~cm}$. Genotypes namely Purple 
Vienna-I (55.67), Purple Vienna-II (53.11), King of Market-I (53.11), Mamta (51.82), SJKK-02 (51.21), King of Market -II (49.34), G-40 (48.73), SJKK-04 (48.67), SJKK-05 (48.62) and Nawpura Local (48.04) were found to be statistically at par with SKKK-02 (55.78). The plant frame varies from $41.17 \mathrm{~cm}$ in White Vienna to $68.83 \mathrm{~cm}$ in SKKK-02 with an overall general mean of $52.79 \mathrm{~cm}$.

Five genotypes viz., SJKK-02 (67.17), Purple Vienna-I (63.00), Mamta (60.00) and SJKK03 (59.33) were found to be statistically at par with SKKK-02 (68.83).Wide variability was observed for petiole length which ranged between $12.22 \mathrm{~cm}$ in genotype Pusa Virat to $24.84 \mathrm{~cm}$ in genotype SJKK-05. However, the overall general mean of petiole length was $19.96 \mathrm{~cm}$. Only one genotype namely Farashi Lajwari Local (15.33) was statistically at par with genotype Pusa Virat (12.22). The number of leaves per plant varies from 7.56 in genotype Farashi Lajwari Local to 12.40 in genotye SJKK-04 with over all general mean of 10.65. Genotype namely Early Super White Vienna (12.33), C-2002 and G-40 (11.89); SJKK-03 (11.70), Green Gold (11.40); Palam Tender Knob (11.33), SKKK-01, White Vienna and Farashi Safed Local (11.22), Pusa Virat (10.94), Baramullah Local and Sopore Local (10.78) and Ganderbal Local (10.67) were found to be statistically at par with genotype SJKK-04 (12.40) (Table 3).

The leaf length ranged between $17.60 \mathrm{~cm}$ in genotype Early White Vienna to $30.28 \mathrm{~cm}$ in genotype SKKK-02 and Purple Vienna-II with an overall general mean of $23.33 \mathrm{~cm}$. The maximum leaf length was observed in genotype SKKK-02 (30.28) which were statistically at par with genotypes viz., Purple Vienna-II (28.83), Nawpura Local (27.53), King of Market-I (27.39), Rajouri Local (26.94), SJKK-04 (26.37), Purple Vienna-I (26.11) and G-40 (26.03).The leaf width varies from $12.44 \mathrm{~cm}$ in genotype Early White
Vienna to $22.67 \mathrm{~cm}$ in Nawpura Local with an overall general mean of $16.25 \mathrm{~cm}$. Four genotypes namely SKKK-02 (22.22), Ganderbal Local (20.24), Purple Vienna-II (20.11) and Purple Vienna-I (20.04) were found to be statistically at par with Nawpura Local (22.67). With regards to stalk length genotypes with low stalk length is preferred from breeding point of view and it ranged between $0.50 \mathrm{~cm}$ in genotype Pusa Virat and 3 $\mathrm{cm}$ in genotype Nawpura Local with an overall general mean of $2.16 \mathrm{~cm}$. None of the genotypes were found to be statistically at par with Pusa Virat $(0.50 \mathrm{~cm})$. Similar findings were observed by Manaware et al., (2017) in cauliflower and Chura et al., (2016) in cabbage for number of leaves per plant; Santhosha et al., (2015), Sharma et al.,(2018), Chitora and Singh (2013) and Mehra and Singh (2013) for leaf length and leaf width; Kumar et al.,(2017) for petiole length, plant spread; Khan et al., (2010) in kale and Singh and Singh (2003) in cabbage for plant height who also reported wide range of variability for various traits in Brassica oleracea cultivars.

\section{Earliness}

Earliness is highly desirable character in all the vegetables in the sense that the prevailing price in the market is invariably high early in the season (Singh et al., 2017). With respect to days to marketable maturity knolkhol genotype Early Super White Vienna took least number of days after transplanting (45.33) to marketable maturity, whereas, genotype Farashi Lajwari Local took maximum number of days (59.67) with over all general mean of 52.27. Only one genotype G-40 was statistically at par with Early White Vienna with mean value (45.33). These findings are also supported by and Chittora and Singh (2015) and Santhosha et al., (2015) who had also observed significant difference for days to curd initiation and days to marketable curd maturity. 
Table.1 List of genotypes along with the source

\begin{tabular}{|c|c|c|c|}
\hline S. No. & Code & Genotype & Source \\
\hline \multicolumn{4}{|c|}{ Released varieties and advance breeding lines of SKUAST- J and SKUAST- K } \\
\hline 1. & G1 & G40 & SKUAST-J \\
\hline 2. & G2 & SJKK-02 & SKUAST-J \\
\hline 3 & G3 & SJKK-03 & SKUAST-J \\
\hline 4 & G4 & SJKK-04 & SKUAST-J \\
\hline 5 & G5 & SJKK-05 & SKUAST-J \\
\hline 6 & G6 & SKKK-01 & SKUAST-K \\
\hline 7 & G7 & SKKK-02 & SKUAST-K \\
\hline 8 & G8 & SKKK-03 & SKUAST-K \\
\hline \multicolumn{4}{|c|}{ Public Sector Varieties } \\
\hline 9 & G9 & Early White Vienna & Directorate of Agriculture, Jammu \\
\hline 10 & G10 & King of Market-I & Directorate of Agriculture, Jammu \\
\hline 11 & G11 & Early SWV & NFCC, Jammu \\
\hline 12 & G12 & Kargil Local & Kargil \\
\hline 13 & G13 & Purple Vienna-I & JK krishi vikas Cooperative Ltd, Pulwama \\
\hline 14 & G14 & Knolkhol White & JK Krishi Vikas Cooperative Ltd, Pulwama \\
\hline 15 & G15 & King of Market-II & Sultan seeds, Munwarabad \\
\hline 16 & G16 & Purple Vienna-II & Sultan seeds, Munwarabad \\
\hline 17 & G17 & Pusa Virat & IARI, Katrain (HP) \\
\hline 18 & G18 & White Vienna & IARI, Katrain (HP) \\
\hline 19 & G19 & Palam Tender Knob & CSKHPKV,Palampur \\
\hline \multicolumn{4}{|c|}{ Local Germplasm of J \& K } \\
\hline 20 & G20 & Farashi Lajwari Local & Sopore \\
\hline 21 & G21 & Farashi Safed Local & Sopore \\
\hline 22 & G22 & Sopore Local & Sopore \\
\hline 23 & G23 & Baramullah Local & Baramullah \\
\hline 24 & G24 & Ganderbal Local & Ganderbal \\
\hline 25 & G25 & Leh Local & Leh \\
\hline 26 & G26 & Rajouri Local & Rajouri \\
\hline 27 & G27 & Nowpora Local & Nawpora \\
\hline \multicolumn{4}{|c|}{ Private sector hybrids } \\
\hline 28 & G28 & Mamta & Crop Life Hybrid Seeds, Punjab \\
\hline 29 & G29 & Green Gold & Indus Seeds, Banglore \\
\hline 30 & G30 & C-2002 & Century Seeds, New Dehli \\
\hline
\end{tabular}

Table.2 Analysis of variance (mean sum of squares) for quantitative traits in knolkhol (Brassica oleracea var. gongylodes L.)

\begin{tabular}{|l|}
\hline S. No. \\
\hline 1 \\
\hline 2 \\
\hline 3 \\
\hline 4 \\
\hline 5 \\
\hline 6 \\
\hline 7 \\
\hline 8 \\
\hline 9 \\
\hline 10 \\
\hline 11 \\
\hline 12 \\
\hline 13 \\
\hline 14 \\
\hline
\end{tabular}

\begin{tabular}{l} 
Source of variation/ Characters \\
\hline Degrees of freedom \\
Plant height $(\mathrm{cm})$ \\
\hline Plant frame $(\mathrm{cm})$ \\
\hline Petiole length $(\mathrm{cm})$ \\
Number of leaves /plant \\
Leaf length $(\mathrm{cm})$ \\
\hline Leaf width $(\mathrm{cm})$ \\
\hline Stalk length $(\mathrm{cm})$ \\
\hline Gross weight/plant $(\mathrm{g})$ \\
\hline Marketable knob weight/plant $(\mathrm{g})$ \\
\hline Marketable knob diameter $(\mathrm{cm})$ \\
\hline Harvest index $(\%)$ \\
\hline Days to marketable maturity \\
Yield per plot $(\mathrm{kg} / \mathrm{plot})$
\end{tabular}

\begin{tabular}{|c|c|c|}
\hline Genotypes & Error & CD (5 \%) \\
\hline $130.74 * *$ & 31.94 & 6.42 \\
\hline $152.86^{* *}$ & 34.87 & 6.71 \\
\hline $21.72 * *$ & 5.06 & 2.56 \\
\hline $3.83 * *$ & 1.32 & 1.31 \\
\hline $39.78^{* *}$ & 9.48 & 3.50 \\
\hline $22.07 * *$ & 3.68 & 2.18 \\
\hline $1.18^{* *}$ & 0.12 & 0.39 \\
\hline $10712.23 * *$ & 2468.14 & 56.45 \\
\hline $6431.748^{*}$ & 1747.62 & 47.50 \\
\hline $1.48 *$ & 0.25 & 0.57 \\
\hline $96.31 * *$ & 17.85 & 4.80 \\
\hline $38.47 * 8$ & 4.31 & 2.36 \\
\hline $1292.27 * *$ & 255.80 & 10.99 \\
\hline
\end{tabular}


Table.3 Mean performance of Knolkhol (Brassica oleracea var. gongylodes L.) for various quantitative traits during main season (Sept-Oct 2016-17)

\begin{tabular}{|c|c|c|c|c|c|c|c|c|c|c|c|c|c|}
\hline Genotype & $\begin{array}{c}\text { Plant height } \\
(\mathbf{c m})\end{array}$ & $\begin{array}{l}\text { Plant } \\
\text { frame } \\
(\mathrm{cm})\end{array}$ & $\begin{array}{l}\text { Petiole } \\
\text { length } \\
\text { (cm) }\end{array}$ & $\begin{array}{l}\text { Number of } \\
\text { leave per } \\
\text { plant }\end{array}$ & $\begin{array}{c}\text { Leaf } \\
\text { length } \\
(\mathrm{cm})\end{array}$ & $\begin{array}{c}\text { Leaf } \\
\text { width } \\
(\mathrm{cm})\end{array}$ & $\begin{array}{l}\text { Stalk } \\
\text { length } \\
(\mathrm{cm})\end{array}$ & $\begin{array}{c}\text { Gross } \\
\text { weight } \\
\text { per } \\
\text { plant (g) }\end{array}$ & $\begin{array}{l}\text { Marketable } \\
\text { knob weight } \\
\text { per plant (g) }\end{array}$ & $\begin{array}{r}\text { Marketable } \\
\text { knob } \\
\text { diameter } \\
(\mathrm{cm})\end{array}$ & $\begin{array}{c}\text { Harvest } \\
\text { Index }(\%)\end{array}$ & $\begin{array}{c}\text { Days to } \\
\text { marketable } \\
\text { maturity }\end{array}$ & $\begin{array}{l}\text { Yield per } \\
\text { plot }(\mathbf{k g})\end{array}$ \\
\hline $\mathrm{G}_{1}(\mathrm{G}-40)$ & 48.73 & 52.67 & 20.56 & 11.89 & 26.03 & 18.63 & 1.68 & 516.77 & 426.80 & 7.63 & 82.66 & 46.67 & 5.96 \\
\hline $\mathbf{G}_{2}$ (SJKK-02) & 51.21 & 51.08 & 21.44 & 12.33 & 23.98 & 16.63 & 1.86 & 520.75 & 413.37 & 7.07 & 79.68 & 49.78 & 4.96 \\
\hline $\mathbf{G}_{3}(\mathrm{SJKK}-03)$ & 46.33 & 59.33 & 20.77 & 11.70 & 23.13 & 16.26 & 1.58 & 507.19 & 400.28 & 7.05 & 79.21 & 49.67 & 4.80 \\
\hline $\mathrm{G}_{4}(\mathrm{SJKK}-04)$ & 48.67 & 51.17 & 21.38 & 12.40 & 26.37 & 16.90 & 1.93 & 530.13 & 447.29 & 7.61 & 84.25 & 49.33 & 6.04 \\
\hline G5 (SJKK-05) & 48.62 & 54.50 & 24.84 & 11.00 & 24.22 & 15.46 & 2.00 & 496.75 & 397.01 & 7.20 & 79.73 & 50.00 & 4.76 \\
\hline $\mathrm{G}_{6}(\mathrm{SKKK}-01)$ & 44.06 & 51.67 & 22.62 & 11.22 & 23.91 & 14.58 & 2.16 & 420.27 & 325.78 & 6.63 & 77.62 & 50.00 & 4.15 \\
\hline $\mathbf{G}_{7}(\mathrm{SKKK}-02)$ & 55.78 & 68.83 & 22.78 & 9.44 & 28.83 & 22.22 & 2.92 & 508.78 & 357.86 & 6.97 & 70.38 & 55.00 & 4.56 \\
\hline $\mathrm{G}_{8}(\mathrm{SKKK}-03)$ & 43.60 & 56.83 & 19.11 & 10.11 & 22.89 & 14.63 & 2.28 & 405.00 & 332.46 & 7.21 & 81.97 & 50.33 & 4.24 \\
\hline G9 (Early White Vienna) & 37.19 & 43.17 & 18.22 & 10.00 & 17.60 & 12.44 & 1.36 & 425.00 & 374.00 & 7.10 & 88.19 & 49.67 & 4.77 \\
\hline $\mathrm{G}_{10}$ (King of Market-I) & 53.11 & 46.17 & 21.69 & 11.00 & 27.39 & 17.65 & 1.91 & 440.43 & 337.65 & 6.98 & 76.11 & 55.00 & 5.29 \\
\hline $\begin{array}{l}G_{11} \text { (Early Super White } \\
\text { Vienna) }\end{array}$ & 44.08 & 52.50 & 22.91 & 12.33 & 21.31 & 15.29 & 1.13 & 491.73 & 444.38 & 7.93 & 90.50 & 45.33 & 6.10 \\
\hline $\mathbf{G}_{12}($ Kargil Local $)$ & 43.56 & 49.00 & 19.18 & 10.45 & 21.97 & 15.41 & 2.39 & 418.89 & 325.64 & 6.96 & 77.55 & 50.33 & 4.40 \\
\hline $\mathrm{G}_{13}($ Purple Vienna-I) & 55.67 & 63.00 & 20.56 & 9.22 & 26.11 & 20.04 & 2.81 & 530.04 & 378.47 & 7.04 & 71.47 & 56.67 & 4.58 \\
\hline $\mathbf{G}_{14}($ Knolkhol White $)$ & 43.77 & 47.83 & 19.73 & 10.89 & 22.78 & 14.11 & 2.64 & 440.09 & 378.26 & 7.23 & 85.88 & 50.00 & 4.82 \\
\hline $\mathbf{G}_{15}$ (King of Market-II) & 49.34 & 52.17 & 17.06 & 9.11 & 20.48 & 16.00 & 2.55 & 360.23 & 325.17 & 7.13 & 90.22 & 55.00 & 4.06 \\
\hline $\mathrm{G}_{16}$ (Purple Vienna-II) & 53.11 & 58.33 & 22.92 & 9.78 & 28.83 & 20.11 & 2.89 & 461.50 & 356.02 & 6.80 & 77.29 & 57.00 & 4.45 \\
\hline $\mathbf{G}_{17}$ (Pusa Virat) & 31.41 & 46.33 & 12.22 & 10.94 & 18.05 & 15.67 & 0.50 & 332.29 & 281.90 & 5.40 & 85.46 & 59.33 & 3.81 \\
\hline $\mathrm{G}_{18}$ (White Vienna) & 36.00 & 41.17 & 18.22 & 11.22 & 18.42 & 13.00 & 2.80 & 383.43 & 320.72 & 6.83 & 83.63 & 50.33 & 4.33 \\
\hline $\mathbf{G}_{19}$ (Palam Tender) & 37.09 & 49.67 & 16.38 & 11.33 & 18.87 & 14.09 & 2.02 & 427.55 & 360.26 & 7.30 & 84.38 & 50.33 & 5.16 \\
\hline $\mathbf{G}_{20}$ (Farashi Lajwari Local) & 31.04 & 45.83 & 15.33 & 7.56 & 17.61 & 13.95 & 1.62 & 326.67 & 303.43 & 5.63 & 93.09 & 59.67 & 4.10 \\
\hline G21 (Farashi Safed Local) & 35.34 & 47.00 & 19.90 & 11.22 & 20.06 & 13.11 & 1.87 & 429.45 & 365.10 & 7.33 & 85.61 & 52.63 & 4.90 \\
\hline $\mathbf{G}_{22}$ (Sopore Local) & 41.78 & 57.67 & 20.11 & 10.78 & 26.22 & 17.28 & 2.70 & 423.89 & 337.78 & 6.40 & 79.74 & 56.67 & 4.05 \\
\hline $\mathbf{G}_{23}$ (Baramullah Local) & 40.76 & 43.00 & 19.16 & 10.78 & 20.91 & 13.36 & 2.83 & 362.78 & 280.65 & 6.00 & 77.75 & 50.89 & 3.58 \\
\hline $\mathbf{G}_{24}$ (Ganderbal Local) & 44.44 & 58.67 & 21.61 & 10.67 & 25.22 & 20.24 & 2.21 & 455.66 & 373.27 & 6.11 & 81.99 & 50.48 & 4.48 \\
\hline $\mathbf{G}_{25}$ (Leh Local) & 39.38 & 51.50 & 16.77 & 10.33 & 19.79 & 14.40 & 2.48 & 389.45 & 310.97 & 6.76 & 79.80 & 50.67 & 3.96 \\
\hline $\mathbf{G}_{26}($ Rajouri Local $)$ & 45.29 & 49.17 & 21.33 & 8.78 & 26.94 & 15.72 & 1.22 & 383.89 & 300.19 & 4.63 & 78.16 & 56.00 & 3.60 \\
\hline $\mathbf{G}_{27}$ (Nawpura Local) & 48.04 & 59.00 & 24.22 & 10.00 & 27.53 & 22.67 & 3.00 & 472.78 & 343.37 & 6.82 & 72.33 & 56.33 & 4.12 \\
\hline $\mathbf{G}_{28}$ (Mamta) & 51.82 & 60.00 & 19.22 & 9.78 & 30.28 & 18.60 & 2.97 & 520.00 & 390.64 & 7.10 & 75.19 & 56.67 & 4.98 \\
\hline $\mathbf{G}_{29}$ (Green Gold) & 45.80 & 44.17 & 19.44 & 11.40 & 23.95 & 15.30 & 2.63 & 497.78 & 428.93 & 7.60 & 86.19 & 49.00 & 5.57 \\
\hline$G_{30}(C-2002)$ & 42.50 & 49.17 & 19.11 & 11.89 & 20.28 & 13.80 & 1.88 & 460.11 & 400.56 & 7.30 & 87.04 & 49.33 & 5.31 \\
\hline GM & 44.58 & 51.78 & 19.96 & 10.65 & 23.33 & 16.25 & 2.16 & 444.64 & 360.61 & 6.86 & 81.44 & 52.27 & 4.66 \\
\hline SE $m \pm$ & 3.26 & 3.41 & 1.30 & 0.66 & 1.78 & 1.11 & 0.20 & 28.68 & 24.14 & 0.29 & 2.44 & 1.20 & 0.29 \\
\hline $\mathrm{CV}(\%)$ & 12.68 & 11.19 & 11.28 & 10.79 & 13.20 & 11.81 & 16.01 & 11.17 & 11.59 & 7.27 & 5.19 & 3.96 & 10.91 \\
\hline $\mathrm{CD}(0.05)$ & 9.24 & 9.65 & 3.68 & 1.88 & 5.03 & 3.14 & 0.57 & 81.20 & 68.33 & 0.82 & 6.90 & 3.39 & 8.26 \\
\hline
\end{tabular}




\section{Yield and yield attributing traits}

Marketable knob diameter, gross weight per plant, marketable knob weight per plant, yield per plot and harvest index are the important traits which reflects the yield potential of particular genotype. Marketable Knob diameter was found maximum in genotype Early White Vienna (7.93) and was minimum (4.63) in Rajouri Local with an overall general mean of $6.86 \mathrm{~cm}$. Genotypes namely G-40 (7.63), SJKK-04 (7.61), Green Gold (7.60), Farashi Safed Local (7.33), Palam Tender Knob (7.30), Knolkhol White (7.23), SKKK-03 $(7.21 \mathrm{~cm})$, SJKK-05 $(7.20 \mathrm{~cm})$ and King of Market-II $(7.13 \mathrm{~cm})$ found to be statistically at par with Early Super White Vienna $(7.93 \mathrm{~cm})$. The gross weight per plant measured varied from $326.67 \mathrm{~g}$ in genotype Farashi Lajwari Local to $530.13 \mathrm{~g}$ in genotype SJKK-04 with an overall general mean of 444.64 g. Genotypes namely Purple Vienna-I (530.04), SJKK-02 (520.75), Mamta (520.00), G-40 (516.77), SKKK-02 (508.78), SJKK-03 (507.19), Green Gold (497.78), SJKK-05 (496.75), Early Super White Vienna (491.73 g), Nawpura Local (472.78 g) and Purple Vienna-II (461.50) were found to be statistically at par with SJKK-04 (530.13). The highest marketable knob weight/plant of $447.29 \mathrm{~g} / \mathrm{plant}$ was recorded in genotype SJKK-04 and the lowest of $280.65 \mathrm{~g} / \mathrm{plant}$ in genotype Baramulah Local with overall general mean of $360.61 \mathrm{~g} / \mathrm{plant}$. Genotypes viz., Early Super White Vienna (444.38), Green Gold (428.93), G-40 (426.80), SJKK02 (413.37), C-2002 (400.56), SJKK-03 (400.28), SJKK-05 (397.01) and Mamta (390.64) were statistically at par with SJKK04 (447.29). Harvest index varied from $70.38 \%$ in genotype Purple Vienna-I to 93.09 $\%$ in genotype Farashi Lajwari Local with an overall general mean of $81.44 \%$. The maximum harvest index was observed in genotype Farashi Safed Local (93.09) which were statistically at par with five genotypes viz., Early Super White Vienna (90.50), King of Market-II (90.22), Early White Vienna (88.19), C-2002 (87.04) and Green Gold (86.19) and the yield/plot varied from 3.58 $\mathrm{kg} / \mathrm{plot}$ in genotype Baramullah Local to 6.10 $\mathrm{kg} /$ plot in genotype Early Super White Vienna with an overall general mean of 4.64 $\mathrm{kg} /$ plot. Four genotypes namely SJKK-04 (6.04), G-40 (5.9), Green Gold (5.57), C-2002 (5.31) and King of Market-I (5.29) were found to be statistically at par with Early Super White Vienna (6.10kg/plot). Considerable amount of variability was observed with respect to range and mean values all the traits studied. The results are in agreement with those of Manaware et al., (2017) in cauliflower and Chura et al., (2016) in cabbage; Sharma et al., (2018) and Santhosha et al., (2015) who had also reported considerable variation for gross weight per plant and marketable yield per plant in cauliflower and Kumar et al., (2017) for harvest index.

\section{References}

Anonymous 2014. Area and production of crop in J\&K. Annual report, Department of Agriculture, Jammu. pp. 89.

Chittora, A. and Singh, D. K. 2015. Genetic variability studies in early cauliflower (Brassica oleracea var. botrytis L.). Electronic Journal of Plant Breeding, 6(3): 842-847.

Chura, A., Negi, P. S., Pandey, V. 2016.Assessment of heritability and genetic advancement for yield and yield attributing traits in cabbage (Brassica oleracea var. capitata L.). International Journal of agricultural Innovation and Research, 5(1): 2319-1473.

Khan, S. H., Ahmed, N., Jabeen, N., Chatoo, M. A. And Hussain, K. 2010. Biodiversity of kale (Brassica oleracea var. acephala) in Kashmir valley. The 
Asian Journal of Horticulture, 5(1): 208-210.

Kumar, V., Singh, D. K. and Panchbhaiya, A. 2017. Genetic variability studies in midseason cauliflower (Brassica oleracea var. botrytis L.). Bulletin of Environment, Pharmacology and Life Sciences, 6(9): 99-104.

Manaware, D., Naidu, A. K. and Lal, N. 2017. Genetic diversity assessment for growth and yield traits in cauliflower. International Journal of Current Microbiology and Applied Science, 6(8): 3016-3027.

Mehra, D. and Singh, D. K. 2013. Studies on genetic variability for yield and its contributing attributes in early cauliflower (Brassica oleracea var. botrytis L.). Pantnagar Journal of Research, 11(2): 261-265.

Panse, V. G. and Sukhatmea, P. V. (eds.). 1967. Statistical Methods for Agricultural Workers, pp.361. ICAR, New Delhi, India.

Santhosha, H. M., Varalakshmi, B. and Manohar, R. K. 2015. Evaluation of early cauliflower (Brassica oleracea var. botrytis L.) germplasm under tropical conditions for various horticultural traits. The bioscan, 10(4): 1631-1635.

Thamburaj, S. and Singh, N. 2010. Text book of vegetables, tuber crops and spices. ICAR, New Delhi, pp. 142.

\section{How to cite this article:}

Rinchan Dolkar, R.K. Samnotra, Sanjeev Kumar, R.K. Gupta and Sandeep Chopra. 2018. Mean Performance of Knolkhol (Brassica oleracea var. gongylodes L.) Genotypes for Various Quantitative Traits under Sub Tropical Conditions of Jammu. Int.J.Curr.Microbiol.App.Sci. 7(06): 900-906. doi: https://doi.org/10.20546/ijcmas.2018.706.106 